\title{
A framework for urban integration. The case of Buenos Aires
}

\author{
Séverine Deneulin, Eduardo Lépore, Ann Mitchell and Ana Lourdes Suárez ${ }^{1}$
}

\begin{abstract}
Summary
Like other Latin American cities, Buenos Aires is deeply fragmented between the formal city and informal settlements. This chapter explores how the capability approach can inform innovative policies to reduce urban inequalities and promote a better distribution of wellbeing opportunities within a given urban territory. After setting the context, the chapter discusses some features of the capability approach which can underpin policies to reduce urban fragmentation. It focuses on three features which are particularly relevant for the context of urban inequality and policy in Latin America: its multi-dimensional, institutional and agentic policy perspective.
\end{abstract}

\section{Introduction}

Latin America is the most urbanized continent, with 80 per cent of its population living in urban areas. A third of Latin Americans live in cities with more than 1 million people (CEPAL, 2014). Argentina does not escape this Latin American characteristic. About 90 per cent of its population is urban, and a third of its overall population - about 15 million of its 45 million inhabitants - is concentrated in the metropolitan area of Buenos Aires.

Latin America has also long been the most unequal continent (Cornia, 2014; LopezCalva et al. 2015), and its cities mirror that inequality. In 2010, a quarter of the Latin American population lived in informal settlements. While this proportion has been decreasing since 1990, it has increased in absolute terms, reaching 111 million in 2012 (UN Habitat, 2012, p. xii). The Latin American city is characterised by a deep fragmentation between 'the slums and the rest' (Rodgers et al., 2011, p. 560). Argentina has followed the same urban fragmentation trend. According to a survey of seven urban agglomerations which contain 60 per cent of the total Argentinian population, there were 1834 informal settlements in the country in 2013 totalling more than 532 thousand families (TECHO, 2013). ${ }^{2}$ The City of Buenos Aires, ${ }^{3}$ which counts 3 million people, has 41 informal settlements in which more than 200,000 people live (Suárez et al., 2014).

This chapter aims "to put into praxis the human development approach", as the introduction to this volume puts it, in the context of urban inequality in Latin America. It responds to the urgent need for alternatives of social policy by examining what specific innovative insights this lens, or novel approach to social policy, can give to inform interventions towards decreasing urban fragmentation and a better distribution of wellbeing opportunities (capabilities) across a given urban territory. It is divided as follows. Section 2 discusses the features of the capability approach which are most relevant in the context of the Latin American city, namely its multi-dimensional and sectoral, institutional and agentic perspective. Section 3 uses the first feature to analyse the dynamic interaction between youth employment and education in informal settlements, and territorial characteristics. Section 4 considers the second feature and analyses the role of civil society organisations in the dynamics of capability expansion in informal settlements. Section 5 discusses the agentic feature to examine the role culture and religion can play in fomenting agency and capability

\footnotetext{
1 We thank the British Academy International Partnership Mobility Scheme grant number PM150043 for facilitating the writing of the chapter.

2 TECHO (2013) considered as informal settlement a set of dwellings with a minimum of eight families, of which more than half lack land titles and access to at least two basic services like water, electricity or sewage.

${ }^{3}$ The City is the Capital of the Federal Republic of Argentina. It has the status of Autonomous City since 1994.
} 
expansion. Section 6 summarizes 'capability-friendly policy' in the context of the fragmented and unequal character of the Latin American city.

\section{A conceptual framework to reduce urban inequality}

The 'right to the city' has been a dominant theoretical lens to analyse inequality in an urban context. The idea originated in the late 1960s, in the work of French sociologist Henri Lefèbvre, as a response to the growing commodification of urban space, and its exchange value in property market increasingly taking over its use value. His proposal was for all urban residents to take part in the decisions that affected their lives, and the creation of new urban spaces that would be valued for their use by residents (Brown, 2013). It was not about participation of citizens in formal structures of urban governance, but political participation aimed at transforming the economic processes to replace the exchange value of urban space with its use value (Harvey, 2008; Kuymulu, 2013; Purcell 2013).

The 'right to the city' became prominent in international institutional discourses when the 2010 World Urban Forum took it as its rallying theme, but its original Marxist emphasis on the de-commodification of land had given way to greater emphasis on equitable distribution of opportunities to realize human rights and citizen participation in existing governance structures. Policy discussions in relation to equal opportunities for housing, health services, basic infrastructure, education and employment are now shaped by discourses around equity and the Sustainable Development Goals. ${ }^{4}$ This section argues that the capability approach could be a unifying framework to incorporate the new shift towards equity and sustainable development in the city without losing the original insights of 'the right to the city'.

The capability approach was precisely introduced as a contribution to discussions about equality. Sen argued that the 'capability space' was more appropriate than the space of income, resources or primary goods to think about equality (Sen 1999). Later on, Sen brought his idea of capability to discussions about justice (Sen 2009), with the normative claim that treating each person as equal implied a distribution of economic and social resources in such a way as to ensure the realisation of a set of basic capabilities for all (Alexander, 2008).

A first feature of framing policies with the capability approach is its multidimensional and multi-sectoral perspective and its evaluative orientation. It is foremost a comparative framework which helps evaluate whether one situation is better than another (Sen 2009), whether people in one neighbourhood live better than another or better than its past residents. The capability approach provides a normative framework to assess what a 'better' life could consist of, and provides criteria or evaluation tools to measure what kind of lives people are able to live. Sen proposes a set of basic functionings, or 'beings and doings', to assess how well people are living, such as being adequately nourished, being free from easily preventable diseases, reading and writing or participating in the life of the community. There could also be more complex valuable functionings. Frediani (2015) adds for example the capability to extend one's house as one capability people who live in informal settlements have reason to value. Some, like Nussbaum (2011), have proposed a specific list of central human functionings to assess how well people are living.

To reflect the dynamic of this multi-dimensional perspective, Wolff and De-Shalit (2007, p. 133) have introduced the ideas of 'corrosive disadvantages' and 'fertile functionings'. Often disadvantages (lack of functionings) cluster together to reinforce each

\footnotetext{
4 The theme of the $7^{\text {th }}$ World Urban Forum, in Medellín, Colombia, in April 2014, was 'Urban Equity in Development'. See Cohen (2016) for a discussion on the SDGs in context of urban inequality.
} 
other negatively. As the next section will discuss, the very fact of living in one specific neighbourhood can be corrosive and lead to poorer education, lower health outcomes and fewer employment opportunities. On the other hand, functionings often cluster together to reinforce each other positively. Because of its multi-dimensional perspective, the capability approach makes possible an analysis of how different wellbeing dimensions affect each other.

A second feature of using the capability approach to frame policy is its institutional perspective. To be free from easily preventable diseases, there needs to be equal access to public health care or safe water so that those who do not have the means to pay for a vaccine or water purification have the same opportunities to avoid early death as those born in higher income families. To be adequately nourished, there needs to be institutions in place that ensure adequate food distribution, with no price distortion, or, in some contexts, public provision of school meals so that all children have equal opportunities to concentrate at school independently of their family situation. Well-functioning institutions of all kinds are essential ingredients of people's quality of life. An unregulated property market, and insufficient provision of low-rent housing, may create homeless families. A corrupt police force that cooperates with criminal gangs may create violent and insecure environments. Lack of coordination between different levels of a government in a given territory, and competition between them because of different political party allegiance, or lack of coordination between state and civil society actors, may lead to poor or insufficient access to basic services.

Given the overarching importance of institutions in the capability framework, Stewart (2013) made the case for broadening the policy evaluation space beyond what individuals can be or do, to include what institutions can be or do - what she calls 'social competencies'. There is a close connection between what institutions can be or do and the relationships among the people who construct or constitute those institutions. For example, the institution of labour market does not function well if some of its constituents relate to certain groups of people with prejudice because of where they live. The housing market institution does not function well when some groups relate to the urban space for the sole aim of property speculation without concern for providing affordable housing. When institutions function badly, individual action is often powerless at transforming them. This is why building social competences requires collective action so that institutions, such as planning laws and housing market, function well and provide the conditions for all urban residents to enjoy basic capabilities.

A third feature of the capability approach is its agentic perspective. Human beings are not passive recipients of state benefits, or passive victims of badly functioning institutions, they are authors of their lives and shapers of their own environment (Sen 1999). It is not 'fate' that some people live in areas that are under permanent risk of flooding during heavy rains, or in areas whose ground and air are contaminated. Citizens can take action to change this state of affairs, and demand the state to build proper water drainage systems or have more efficient waste management, or create a citizen watchdog to monitor environmental regulation compliance of industries operating near the area. Within the capability framework, urban residents are conceived as agents, responsible for creating the economic, social and political conditions for all residents to equally enjoy a basic set of capabilities independently of where they live in the city.

The capability approach does not have a view about specific institutional arrangements which citizens need to create so that all urban residents can equally enjoy a basic set of capabilities, unlike Lefèbvre's right to the city which advocated direct control of urban policy by residents and elimination of capital maximisation from economic production (Purcell, 2013). It has a more modest utopian horizon. Reducing the number of people who 
suffer ill health from environmental contamination or increasing access to green spaces would already make cities better or more just, even if no progress has been made in increasing employment opportunities. It is also not prescriptive regarding the relationship between representative democracy and capitalist interests. It limits itself to emphasising the agency of all residents to change states of affairs, whether through direct participation or through representative organizations. All residents are responsible to act such that policy decisions create the conditions for equal enjoyment of basic capabilities. In that regard, the capability approach puts a great emphasis on 'public reasoning' which it understands as the organizational ability of people who suffer from a capability deprivation to make their voices heard, as the ability to listen to different viewpoints and see the world from the perspective of another person (Drèze and Sen, 2013)

The next sections discuss each in turn these three main features of the capability approach in the context of urban inequality reduction policies in Latin America, focusing on the City of Buenos Aires.

\section{Multi-dimensional dynamics}

The opportunities for young people who live in informal settlements to complete secondary school and secure decent employment is closely associated with multi-dimensional dynamics of deprivation related to residential segregation and segmentation of education services and labour markets. Recent studies carried out in the City of Buenos Aires have shown that the consequences of labour exclusion are heightened when workers live in neighbourhoods of concentrated poverty (Lépore, 2014). Other studies have suggested that the segmentation of educational opportunities confines young residents of informal settlements to poorer educational services (Suárez and Groisman, 2008), and that territorial stigmatization operates as a mechanism of discrimination in access to formal labour markets (Kessler, 2012). It has also been demonstrated that conditions of concentrated poverty give rise to marginal subcultures stemming from collective experiences of disaffiliation sustained over time. These sub-cultures often operate as reference frameworks for what segregated young people do and 'value being and doing', and often generate fatalistic beliefs about their future and their expectations of social mobility (Kaztman, 2001). Thus, what Wolff and De Shalit (2007) coined as 'corrosive disadvantages' do not solely impact the realization of wellbeing of young people, but also impact their subjective perceptions of opportunities for attaining wellbeing.

Linking the capability approach with other perspectives for analysing urban segregation, such as that of 'neighbourhood effects of concentrated poverty,' helps us to better understand the multi-dimensional dynamics of capability deprivation among young people and the consequences for urban integration. The urban segregation approach highlights disparities in the spatial distribution of social and economic opportunities. One of its main theses is that residential segregation acts as a mechanism that reproduces the very urban inequalities of which it is a manifestation (Massey and Denton, 1993). Residential segregation generates a 'social isolation of the poor', who have daily contact with equally disadvantaged peers, thus reducing their horizon of possibilities (Kaztman, 2001). It narrows the spaces of interaction between different social groups, increasing educational and labour market segmentation (Kaztman and Retamoso, 2005, 2007), and may also affect the quality of community life and the capacity for collective action, both of which are associated with violence and social disorganization (Sabatini et al., 2001).

Research on urban segregation highlights two dimensions of the multi-dimensional dynamics of disadvantages briefly mentioned above. The first relates to the territorial concentration of poverty and its influence on processes of socialization and access to 
opportunities. The second focuses on the integration of these territories into the urban social fabric. A central methodological contribution of this literature has been that of 'neighbourhood effects' (Wilson, 1996). According to this approach, living in a deprived neighbourhood has a negative effect on residents' life chances beyond their individual characteristics. This is particularly the case for children and young people who have been exposed to territorially-concentrated poverty for a prolonged period of time. Empirical research has yielded some consistent conclusions with respect to the impact of various social and ecological characteristics of the residential surroundings on indicators such as: infant mortality, low birth weight, teen pregnancy, school drop outs, school attainment, the development of cognitive abilities, child abuse, access to employment and youth criminality (Jencks and Mayer, 1990; Sampson et al., 2002; Murry et al., 2011). ${ }^{5}$

The findings of our research in informal settlements of Buenos Aires highlight the relationship between spatially concentrated poverty and the labour market, and their consequences for the opportunities young people have to be in secure employment and to be educated at the secondary level. It corroborates the influence of the geographical concentration of disadvantages on key indicators of youth marginalization, taking also into account the effects of the educational and occupational status of family members. In particular, the results summarized below come from applying logistic regression models to data on a sample of households from the City of Buenos Aires' Annual Household Survey in 2004 and 2012, and a sample of households living in seven Buenos Aires's informal settlements collected through the Catholic University of Argentina's Survey of Family Living Conditions in 2011-2012 (Lépore and Simpson, 2016).

Firstly, access to formal employment is conditioned by the socioeconomic make-up of the neighbourhoods where young people live. The risk of marginal employment increases significantly when young people reside in informal settlements, independently of other considered factors. In addition to neighbourhood effects, both the educational and occupational status of family members are factors that have a statistically significant influence on young people's employment outcomes. In the case of young people who reside in informal settlements, having parents with a higher level of education is not associated with greater chances of securing formal sector employment. However, participation of a household head in informal employment does increase the risk of youth reproducing these same conditions of occupational informality in a statistically significant manner.

Secondly, youth's educational attainment is also affected by the effects of spatially concentrated poverty. Living in an informal settlement significantly increases the likelihood of dropping out of school, not attending school and not completing secondary education. The educational environment of the household has a significant effect on reducing the relative risk of educational deprivation. In contrast, the occupational status of household members is not significantly associated with any of these indicators. In informal settlements, when the household's main income earner is in a situation of occupational marginality, the risk of adolescents dropping out of secondary school increases relative to that of adolescents living in households in which the main earner is employed in the formal sector.

Thirdly, residing in an informal settlement contributes to an increased likelihood of a young person neither working nor studying, nor seeking employment, independently of other socio-demographic and economic factors. For young residents of informal settlements,

\footnotetext{
${ }^{5}$ The analysis of 'neighbourhood effects' is not free of methodological difficulties. The literature identifies two central problems with measuring the effects of the residential context on individual outcomes: selection bias and endogeneity of simultaneity (Sampson et al., 2002).
} 
neither the educational climate of the household, nor the occupational status of household members has a statistically significant influence on institutional marginalization.

The analysis of these statistical findings suggests that the spatial concentration of disadvantages, combined with labour market segmentation, is a main determinant of urban marginality. Therefore, participation in marginal labour market among residents of segregated neighbourhoods increases the risk of youth social marginalization in a significant and cumulative fashion.

This empirical evidence has a number of important implications for social policy. Among others, it draws attention to the insufficiency of conditional cash transfer programs to tackle the consequences of concentration of disadvantages on educational and employment outcomes for young people who live in deprived communities. The deficits in educational and employment outcomes are not as much associated with the absence of human capital and family income as with the logic of territorial discrimination and stigmatization, which prevents disadvantaged young people from accessing opportunities. It also confirms that employment policies directed at increasing employability among disadvantaged young people are often not effective in counteracting the barriers that residential segregation causes in accessing formal labour markets. This is why capability-friendly policies, or policies seeking to reduce disadvantages in unequal urban contexts, imply first of all a comprehensive approach that addresses the dynamics of capability deprivation in a multi-dimensional and multi-level setting. There is an urgent need to combine housing opportunities with investments in social services, education, transportation, job readiness, training and placement at local and neighbourhood levels. Specifically, in the case of young residents of segregated neighbourhoods, there is a need for mechanisms and incentives which promote in a combined and integrated way educational quality, employment training opportunities and workplace training in the formal economy. From an urban integration perspective, the main challenge is overcoming the residential and occupational circuits of marginality in which young people who live in enclaves of concentrated disadvantaged are trapped. In this respect, international development practices suggest two principal directions: either to lift up neighbourhoods of concentrated poverty through community development, including improvement of public infrastructure which is also known as "urbanisation of informal settlements', or help poor people to disperse into socially and economically mixed areas. The next section examines the first option: the role of civil society and community organizations in addressing multiple disadvantages in neighbourhoods of concentrated disadvantages.

\section{Building institutions}

Civil society organizations (CSO) provide an institutional structure through which community members can deliberate, channel common demands, act collectively, and build, what Stewart (2013) called, social competencies. This section uses the case of the civil society sector of the informal settlements of the City of Buenos Aires to analyse the sector's role in expanding individual capabilities and collective agency in marginalized communities (Mitchell, 2016). The analysis is based on a civil society organization survey and a household survey carried out during 2011-12 in seven of the City's informal settlements. ${ }^{6}$

The CSO survey identified a total of 195 organizations operating within the boundaries of the seven settlements, or an average of 1.8 organizations per thousand

\footnotetext{
${ }^{6}$ These were villas 24, 1-11-14, 6,19 and 3, Piletones and the housing complex Ramon Carrillo. According to the 2010 census, the combined population of these settlements is 106,000, approximately two-thirds of the population living in informal settlements in the city. See Lépore et al. (2012) for a description of the surveys.
} 
residents. This means that the organizational density in the settlements is somewhat below the Argentine average of 2.9, but above that of other Latin American countries, such as Brazil, which has an average of only 0.7 (Cao et al., 2011). The scale of civil society activity is comparatively higher when based on the total number of participants. According to the same survey, 3 per cent of residents collaborate as volunteers and nearly half of all residents participate in the activities of at least one organization. The finding of a dense network of organizations operating in these communities contrasts with the results of some research which has found an erosion of networks of organizations and institutions in segregated communities (Pereira Leite, 2008; Wacquant, 2008).

Six out ten CSOs are grassroots organizations ${ }^{7}$ and the rest are faith-based organizations, social movements and social service oriented non-governmental organizations. While the bonds of trust and cooperation among community members were decisive in the creation of grassroots organizations, the construction of alliances with institutions and people from outside of the community have been vital to expanding social connectivity and enabling organizations to gain access to economic resources and diversify their activities. The public sector is the primary source of CSO financing. Eight out of ten grassroots organizations obtain economic resources from either the city or the national government and many organizations focus their activities on the administration of programs designed and financed by the public sector.

The principal purpose of over half of the organizations operating in these settlements is the provision of social services, especially food. Nearly a hundred community kitchens operate in these neighbourhoods, providing daily rations of food to around a quarter of all residents. Half of all organizations provide some type of education services, such as afterschool programs, day-care centres, nursery schools and adult literacy programs. Two out of ten organizations offer programs to increase the productive and labour market opportunities of residents, such as job training (carpentry, auto-mechanics, computers, etc.) and microcredit programs. The most important health-related activities are drug treatment programs and workshops on topics such as reproductive health, oral hygiene and nutrition.

There is broad evidence, therefore, that the dense network of organizations operating in these communities contributes to the expansion of individual capabilities (to be well nourished, to be educated, to be healthy, to have opportunities for recreation, etc.) through the provision of social services. The organizations also provide spaces in which community members can interact, socialize and converse, thereby expanding their capability of affiliation. But, to what extent do CSOs provide mediums through which individuals can become active agents in their lives, where through deliberation they can define which goals they value most and collectively work to pursue those goals?

Nearly all of the City's informal settlements have one principal representative organization which is the main vehicle for advancing the community's collective demands. These organizations, whose origin dates in some cases back to the 1950s, have been instrumental in the transformation of land occupations into neighbourhoods. While their primary demands focused initially on gaining access to basic public services (water, sewerage and electricity), the demands shifted later to obtaining paved roads, streetlights and community health centres and more recently to improving the quality of public services and procuring ambulance services. As one resident stated, 'The things that have been done are because the people organize themselves. The changes were gradual and always depended on

\footnotetext{
${ }^{7}$ If all of the people directly involved in the organization's creation were living in the community at the time it was created, the organization was classified as grassroots.
} 
the capacity for organization of the neighbourhood and the political orientation of the city's government'. 8

While street blockages, occupation of public buildings and other forms of protest have been the methods most frequently used to voice the concerns of the population, the representative organizations have increasingly expressed their demands through the drafting of formal petitions and judicial and legislative processes. The municipal Law 148, sanctioned in 1998, conferred the responsibility for the diagnosis, planning and control of public policies related to the settlements to a coordinating commission comprised of the city government, social movements linked to problems affecting the settlements (movimientos villeros ${ }^{9}$ ) and neighbourhood representative organizations. After years of legal battles, the city government finally organized formal elections for delegates of the representative organizations in nearly all of the settlements. Civil society leaders, however, have denounced irregularities in the electoral processes and delegates complain that opportunities for the representative organizations to participate in the urbanization process are extremely limited, despite the fact that a legal framework exists that should guarantee that right. The government has instead prioritized actions to foster direct contact with community members, by setting up 'portable' government offices in the periphery of the settlements and organizing neighbourhood assemblies to discuss concrete issues facing the community.

In interviews, organization representatives also complained about the lack of internal cohesion within the representative organizations, vested interests between delegates and government officials and a lack of transparency in the allocation of lucrative contracts to organizations for the maintenance and provision of public services. All of these factors contribute to lowering confidence in civil society and weaken the capacity to garner community support for collective initiatives. According to household survey, 41 per cent of respondents trust CSO, 33 per cent trust CSO leaders and only 23 per cent trust the delegates of representative organizations. Moreover, just 6 per cent of respondents indicated that they participate in neighbourhood assemblies and 3 per cent participate in a political party or social movement.

The case shows that while civil society organizations play an integral role in the provision of social services through a relationship of co-production with public sector, their broader role in the processes of integration of the settlements into the city is relatively more limited due to factors intimately related to civil society-state relations, including irregularities in election processes, lack of transparency in the allocation of public resources and the resulting conflict between organizations and the low level of confidence in civil society. True empowerment of community members to work together to obtain common goals requires the strengthening of representative organizations and greater transparency in civil society-state relations. In other words, capability-friendly policies require setting the conditions that enable people to exercise agency in a way that promotes the good of the community. Given that a large number of CSOs which are active in the settlements have a religious foundation, and given the importance of religious expression in these territories of urban marginality (Suárez, 2015), the next section analyses the role that religion could play in expanding capabilities and building social competencies. It focuses on how religion has contributed to shaping the agency of the residents of the informal settlements of the City of Buenos Aires.

\section{Fostering agency}

\footnotetext{
${ }^{8}$ Based on an interview with an organization leader in Piletones conducted on July 12, 2013.

${ }^{9}$ In Argentinian Spanish, informal settlements are called villas miserias, or villas.
} 
Religion has permeated and played an important role in the intense seven decades of history of the informal settlements in the City of Buenos Aires. Processes, discussions, events, institutions and people associated with the religious world have left deep footprints in these territories.

In the 1960s and 1970s, the Argentine Catholic Church was shaken by major changes. The Vatican II Council in Rome from 1962-1965, and the first Latin American Bishops Conference in 1968 in Medellin, Colombia, opened the way to more committed social religious options. It adopted the 'preferential option for the poor' as an institutional commitment. According to this 'option' or conscious choice, those who live in conditions of poverty are to be the primary concern of the Church's pastoral activities (Dorr, 2012; González, 2010). The informal settlements were a 'privileged place' for that commitment; they opened a way to realize this 'preferential option for the poor' launched by the Bishops and widely accepted by many sectors of Catholicism.

A relevant actor in this period was the Movement of Third World Priests (Movimiento de Sacerdotes del Tercer Mundo, or MSTM in its Spanish acronym), which took effect between 1967 and 1976, and which had a strong presence in Buenos Aires's informal settlements. The Catholic priest Carlos Mugica was one of its most emblematic and public figures. He had close ties with Peronism - the political movement in Argentina associated with General Perón and labour rights and redistributive policies. He had a major presence in the national media denouncing the bad living conditions in the City's informal settlements. Mugica came from a wealthy family of Buenos Aires and summoned other priests to live and work in one of the City's biggest informal settlement. His assassination in 1974 at the hands of paramilitary groups shocked the country, marking a milestone in the symbolic burden of these territories, and inspiring many people to work for the poorest in the city.

The figure of these pioneering priests who went to live in informal settlements left a strong mark of commitment, struggle and denunciation which continues to the present day within these territories of urban marginalization (e.g. lack of government presence, lack of adequate political intervention, deterioration of public infrastructure and increasingly worsening living conditions). Other religious actors, such as religious congregations and committed men and women followed suit in choosing the informal settlements as a space for social and Christian commitment. Some female congregations particularly led the way by leaving the schools they ran for the privileged to live a life of 'insertion' among marginalized communities.

During the last military Government (1976-1983) several of the religious actors who were socially and politically engaged, were persecuted, and some tortured and killed. In addition to this political persecution, the Government of the City of Buenos Aires was determined to eradicate completely the informal settlements in the City. Many organizations resisted this attack and several religious actors had a prominent role in the resistance. Their slogan was: integration of all settlements to the city, and appreciation of the culture of its residents, known as 'cultura popular'. Based on statement made by the Catholic priests who live today in the settlements of the City of Buenos Aires, both ideas continue to be held.

The 'closeness' of the Archbishop of Buenos Aires, Jorge Bergoglio, now Pope Francis, ${ }^{10}$ with the residents of informal settlements and the prioritization of social and pastoral action among the city's most marginalized areas, was one of the hallmarks of his model of church governance. He established a more solid and permanent presence of the Church in each of the informal settlement of the City of Buenos Aires; he doubled the

${ }^{10}$ Bergoglio was appointed Archbishop of Buenos Aires in 1998, and was elected Pope in March 2013. 
number of priests in charge of the ministry in these territories (from 11 in 1998 to 22 in 2012); he created also a special pastoral agency to deal specifically with the problems of the settlements, known as 'Pastoral Villera'. Bergoglio therefore gave relevance and support to the Church's pastoral and social action in the most marginalized areas of the city. He himself used to visit the city's informal settlements, and walked in its narrow alleyways like a local resident.

Religious buildings such as churches, chapels, houses of religious congregations, particularly of nuns, have become not only places where residents of informal settlements gather to express their faith, but where many other activities take place. Also they tend to be places where different public services are offered, as the previous section on civil society described: public kitchen offering food for those in need, social services, attention to drug addicted, etc. In short they have become places to pray, celebrate, find help and assistance, and recover. The presence of a church (both Catholic and Pentecostal) ${ }^{11}$ that values and positions itself within territories of urban marginality, redirecting the focus of its mission to disadvantaged people, has an important and revitalizing effect on people's lives and building the institutional conditions for human flourishing.

From a cultural perspective, privileged channels that express ways of being and values are rich manifestations of popular religiosity. They are part of informal settlements residents' matrix of meanings, practices and rituals. Popular religiosity plays a large role in shaping their agency by supporting their cosmologic and holistic cultural matrix from which they feed 'hope' and a positive way of facing their lives. Massive processions in honour of a popular saint, rituals in remembrance of dead people, venerations of 'non officially recognized' religious figures, popular adoration to the virgin Mary, etc., can all be understood as pursuits of recognition, identity and transformation. They do have a social impact, particularly when 'official' Church structures dialogue with them instead of condemning them -as it tends to be the case in some places. Many 'popular' religious manifestations have become spaces of 'resistance' in the city's informal settlements. Through its support, the Church helps shape the vital and transforming power that the residents themselves have to be authors of their lives and transform the world around them.

\section{Conclusion}

This chapter has explored how the capability approach, as an evaluative conceptual framework with normative redistributive claims, can illuminate policies that promote urban integration in Latin America. It has concentrated on three features: its multi-dimensional perspective on human wellbeing, the importance it gives to institutions in their instrumental and constitutive role in people's wellbeing, and the centrality of agency in creating the necessary institutional conditions for people to flourish as human beings. It has used the informal settlements of the City of Buenos Aires as empirical ground to demonstrate the emancipatory potential of using the capability approach as analytical lens to address disadvantages. It has illustrated how capability-friendly policies can be 'operationalized' and

\footnotetext{
${ }^{11}$ According to the survey directed by Suárez (2015), the population in these communities is mostly Christian, like in the rest of the City, but there is a higher proportion of Evangelical, 16 per cent compared to 3 per cent of Evangelicals in the formal areas of the city. Most of these churches are Pentecostals and affiliated to very small and marginal churches located inside the settlements, unlike the Catholic parishes which are linked to other parts of the city. The survey also highlights a high porosity between church belonging, with many residents attending rituals and events of different churches, and professing beliefs of one denomination, e.g. saints in the Catholic Church, and belonging to another denomination.
} 
suggested some ways for policies to become genuine practices of human development which expand people's capabilities and strengthens their agency.

Given the multi-dimensional dynamics of deprivation, especially how territorial characteristics and employment and educational outcomes negatively reinforce each other, an integral perspective on policy is required. There is little point in initiating employability schemes for disadvantaged young people without addressing at the same time housing or infrastructure deficit and territorial discrimination. Civil society organisations can play a large role in this respect. There also needs to be public action oriented at establishing transparent and inclusive mechanisms of representation between residents and state authorities. While civil society organizations provide an invaluable array of services to local residents of the informal settlements, this is not sufficient. In its recognition of agency as a key feature of policy, with people as subjects and not passive recipients, capability-friendly policies also require taking into account the potential of culture, often intertwined with religion, in enabling residents of informal settlements to be actors of their journey towards more fulfilling and flourishing human lives. This is an under-explored area in the social sciences and would deserve greater attention given that 80 per cent of the world's population is estimated to profess religious beliefs which are core to who they are as human beings. If the capability approach, and Sen's Idea of Justice, makes large references to the kinds of human beings people are, which include among other the capacities for reasoning and sympathy (Sen, 2009, pp. 414-5), adding the capacity to relate to a Transcendental source of value, could be an area of significant enrichment for capability-friendly policies.

\section{References}

Alexander, J. (2008) Capabilities and social justice, Farnham: Ashgate.

Brown, A. (2013) 'The right to the city: Road to Rio 2010', International Journal of Urban and Regional Research, 37(3): 957-71.

Cao, C., Cecconi, E. and Balian, B. (2011) La sociedad civil Argentina en el Bicentenario. (2008-2010) [Civil society in Argentina in the Bicentenary], Buenos Aires: GADIS, available at http://gadis-asociacion.org/PublicacionesRecientes.asp.

CEPAL (2014) Social panorama of Latin America and the Caribbean. Santiago: United Nations Economic Commission for Latin America, available at http://www.cepal.org/en/publications/37626-social-panorama-latin-america-2014.

Cohen, M. (2016) 'From Habitat III to Pachamama', Environment and Urbanization, 28: 3548.

Cornia, G. A. (ed.) (2014) Falling inequality in Latin America: Policy changes and lessons, Oxford: Oxford University Press.

Dorr, D. (2012) Option for the poor and the earth, New York: Orbis Books.

Drèze, J. and Sen, A. (2013) An uncertain glory: India and its contradictions, London: Allen Lane.

Frediani, A. (2015) 'Space and capabilities: Approaching informal settlements', in Lemanski, C. and Marx, C. (eds) The city in urban poverty, Cambridge: Cambridge University Press, pp. 64-84.

González, M. (2010) La reflexión teológica en Argentina, 1962-2004 [A theological reflection in Argentina], Buenos Aires: Iberoamérica.

Harvey, D. (2008) 'The right to the city', New Left Review, 53: 23-40.

Jencks, C. and Mayer, S. (1990) 'The social consequences of growing up in a poor Neighborhood', in Lynn, L. E., and McGeary, M. G. H. (eds.) Inner-city poverty in the United States, Washington DC: National Academy Press, pp. 111-85. 
Kaztman, R. (2001) 'Seducidos y abandonados: El aislamiento social de los pobres urbanos' [Seduced and abandoned: The social isolation of the urban poor], Revista de la CEPAL, 75: 171-189.

Kaztman, R. and Retamoso, A. (2005) 'Segregación espacial, empleo y pobreza en Montevideo' [Spatial segregation, employment and poverty in Montevideo], Revista de la CEPAL, 85: 131-148.

Kaztman, R. and Retamoso, A. (2007) 'Efectos de la segregación urbana sobre la educación en Montevideo' [Effects of urban segregation on education in Montevideo], Revista de la CEPAL, 91: 133-152.

Kessler, G. (2012) 'Las consecuencias de la estigmatización territorial' [The consequences of territorial stigmatization', Espacios en Blanco. Revista de Educación, 22: 165-198.

Kuymulu, M. B. (2013) 'The vortex of rights: 'Right to the City' at a crossroads', International Journal of Urban and Regional Research, 37(3): 923-40.

Lépore, E. (2014) 'Participación laboral y modalidades de inserción socio-ocupacional en las villas de la Ciudad' [Labour participation and modalities of socio-occupational insertion in the informal settlements of the City], In Suárez, A. L., Mitchell, A. y Lépore, E. (eds.) Las villas de la Ciudad de Buenos Aires. Territorios frágiles de inclusión social [The informal settlements of the City of Buenos Aires: Fragile territories of social inclusion]. Buenos Aires: Educa, pp. 95-140.

Lépore, E. and Simpson, S. (2016), 'Concentrated poverty and labour markets: Youth marginalization in Buenos Aires's informal settlements', Working Paper Series on Urban Inclusion and Integration, number 2, July 2016, Catholic University of Argentina, http://www.uca.edu.ar/index.php/site/index/es/uca/programa-interdisciplinario-sobredesarrollo-humano-e-inclusion-social/serie-bassp/

Lépore, E., Lépore, S., Mitchell, A., Macció, J. and Rivero, E. (2012) Capacidades de desarrollo y sociedad civil en las villas de la Ciudad [Capabilities for development and civil society in the informal settlements of the City], Buenos Aires: Educa.

Lopez-Calva L.F., Lustig, N. and Ortiz-Juarez, E. (2015) 'A long-term perspective on inequality and human development in Latin America',Journal of Human Development and Capabilities, 16(3), 319-323.

Massey, D. and Denton, N. (1993), American apartheid: Segregation and the making of the underclass, Cambridge: Harvard University Press.

Mitchell, A. (2012) 'Las organizaciones de la sociedad civil en las villas de Bajo Flores y Barracas', in E. Lépore et al. (Ed.), Capacidades de Desarrollo y Sociedad Civil en las Villas de la Ciudad, Universidad Católica Argentina, Buenos Aires, pp. 115-187.

Mitchell, A. (2016) 'Civil society organizations in the informal settlements of Buenos Aires: Service providers and forces for change', Voluntas, 27(1): 37-60.

Murry, V. M., Berkel, C., Gaylord-Harden, N. K., Copeland-Linder, N., and Nation, N. (2011) 'Neighborhood poverty and adolescence development', Journal of Research on Adolescence, 21(1): 114-128.

Nussbaum, M. (2011) Creating capabilities, Cambridge, Mass.: Harvard University Press.

Pereira Leite, M. (2008) 'Pobreza y exclusión en las favelas de Río de Janeiro' [Poverty and exclusion in the favelas of Rio], in Ziccardi, A. (ed.) Procesos de urbanización de la pobreza y nuevas formas de exclusión social [Urbanization processes of poverty and new forms of social exclusion], Buenos Aires: CLACSO.

Purcell, M. (2013) 'Possible worlds: Henri Lefebvre and the right to the city', Journal of Urban Affairs, 36(1): 141-154.

Rodgers, D., Beall, J. and Kanbur, R. (2011) 'Latin American urban development into the twenty-first century', European Journal of Development Research, 23(4): 550-68. 
Sabatini, F., Cáceres, G. and Cerda, J. (2001) 'Segregación residencial en las principales ciudades chilenas' [Residential segregation in the main Chilean cities', Revista EURE Revista de Estudios Urbano Regionales, 29 (89): 5-24.

Sampson, R. J., Morenoff, J. D and Gannon-Rowley, T. (2002), 'Assessing "neighborhood Effects"', Annual Review of Sociology, 28(1): 443-78.

Sen, A. K. (1999) Development as freedom, Oxford: Oxford University Press. (2009) The idea of justice, London: Allen Lane.

Stewart, F. (2013) 'Capabilities and human development: Beyond the individual - The critical role of social institutions and social competencies', UNDP-HDRO Occasional Papers No. 2013/03.

Suárez, A, L. and Groisman, F. (2008) 'Segregação residencial e conquistas educacionais na Argentina' [Residential segregation and educational gains in Argentina], in Queiroz Ribeiro, L. and Kaztman, R. (eds.), A cidade contra a escola?: segregação urbana $e$ desigualdades educacionais em grandes cidades da América Latina [Urban segregation and educational inequality in the big Latin American cities], Río de Janeiro: Letra Capital.

Suárez, A. L., Mitchell, A. y Lépore, E. (eds.) (2014) Las villas de la Ciudad de Buenos Aires. Territorios frágiles de inclusión social. Buenos Aires, Educa

Suárez, A.L. (2015) Creer en las villas. Devociones y prácticas religiosas en barrios precarios de la Ciudad de Buenos Aires [Believing in the informal settlements: Devotions and religious practices in the marginal neighbourhoods of the City of Buenos Aires], Buenos Aires: Biblos.

TECHO Argentina (2013), Relevamiento de asentamientos informales 2013 [Inventory of informal settlements], TECHO: Buenos Aires, available at http://www.techo.org/informate/techo-argentina-relevamiento-asentamientosinformales

Wacquant, L. (2008) Urban outcasts: A comparative sociology of advanced marginality, Cambridge: Polity Press.

Wilson, W. J. (1996) When work disappears: The world of the new urban poor, New York: Random House.

Wolff, J. and De-Shalit, A. (2007) Disadvantage, Oxford: Oxford University Press. 